\title{
EVALUASI STATUS HARA PLUS ONE TEST PADA LATOSOL DENGAN INDIKATOR JAGUNG MANIS
}

\section{Nutrient Status Evaluation Plus One Test on Latosol Using Sweet Corn as Indicator Plant}

\author{
Budi Nugroho1)*, Desi Nadalia'), dan Dewi Hanifah2) \\ 1) Departemen Ilmu Tanah dan Sumberdaya Lahan, Fakultas Pertanian IPB University, Jl. Meranti Kampus IPB \\ Darmaga Bogor 16680 \\ 2) Program Studi Manajemen Sumberdaya Lahan, Departemen Ilmu Tanah dan Sumberdaya Lahan, Fakultas \\ Pertanian, IPB University, Jl. Meranti Kampus IPB Dramaga Bogor 16680
}

\begin{abstract}
The method of evaluating nutrient status with the experimental plus one test technique was conducted to determine the limiting factors. This study was aimed to evaluate the effect of fertilization treatment on the growth, production, and leaf color of sweet corn. The experiment was conducted in Latosol, Dramaga Bogor. The experiment used a single factor treatment design and randomized block environmental design with two replications to obtain 14 experimental units. The plus one test technique

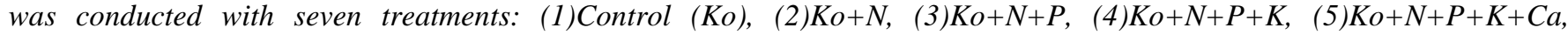
(6) $\mathrm{Ko}+\mathrm{N}+\mathrm{P}+\mathrm{K}+\mathrm{Ca}+\mathrm{Mg}$, (7) $\mathrm{Ko}+\mathrm{N}+\mathrm{P}+\mathrm{K}+\mathrm{Ca}+\mathrm{Mg}+\mathrm{S}$. The fertilizers used are urea $(N), S P-36(P), K C l(K)$, agricultural lime $(\mathrm{Ca}), \mathrm{MgO}(\mathrm{Mg})$, and $\mathrm{ZA}(\mathrm{S})$. The experiment results showed that the nutrient that became the limiting factor was Ca. The result is evident from the results of the DMRT test, which shows that the treatment of $\mathrm{Ko}+\mathrm{N}+\mathrm{P}+\mathrm{K}+\mathrm{Ca}$ has a significant effect on the growth and production of sweet corn. Thus giving agricultural lime is needed for the following fertilization. Besides being able to neutralize soil acidity, agricultural lime also adds Ca nutrients. Based on the RGB value generated from ImageJ software, it can be seen that all fertilization techniques plus one test on average cause a decrease in the RGB value compared to the control treatment, except for the Ko+N treatment an increase in the $G$ value. Thus the addition of nutrients $N, P, K, C a, M g$, and $S$ relatively affect the RGB value. However, the $G$ value has the highest value for each given fertilizer treatment than the $R$ and $B$ values. Even though, the more complete the added nutrients cause the increase in red and blue color uptake.
\end{abstract}

Keywords: Available nutrient, leaf color, limiting factor

\section{ABSTRAK}

Metode evaluasi status hara dengan teknik percobaan plus one test dilakukan untuk menetapkan hara yang menjadi faktor pembatas. Tujuan dari penelitian ini adalah mengevaluasi pengaruh perlakuan pemupukan terhadap pertumbuhan, produksi serta warna daun jagung manis. Percobaan dilakukan di Latosol, Dramaga Bogor. Percobaan menggunakan rancangan perlakuan faktor tunggal dan rancangan lingkungan acak kelompok dengan dua ulangan sehingga diperoleh 14 satuan percobaan. Teknik plus one test dilakukan dengan tujuh perlakuan: (1) Kontrol (Ko), (2) $\mathrm{Ko}+\mathrm{N}$, (3) $\mathrm{Ko}+\mathrm{N}+\mathrm{P}$, (4) $\mathrm{Ko}+\mathrm{N}+\mathrm{P}+\mathrm{K}$, (5) $\mathrm{Ko}+\mathrm{N}+\mathrm{P}+\mathrm{K}+\mathrm{Ca}$, (6) $\mathrm{Ko}+\mathrm{N}+\mathrm{P}+\mathrm{K}+\mathrm{Ca}+\mathrm{Mg}$, (7) $\mathrm{Ko}+\mathrm{N}+\mathrm{P}+\mathrm{K}+\mathrm{Ca}+\mathrm{Mg}+\mathrm{S}$. Pupuk yang digunakan adalah pupuk urea (N), SP-36 $(\mathrm{P}), \mathrm{KCl}(\mathrm{K})$, kaptan $(\mathrm{Ca}), \mathrm{MgO}(\mathrm{Mg})$, dan $\mathrm{ZA}(\mathrm{S})$. Hasil percobaan menunjukkan bahwa hara yang menjadi faktor pembatas adalah $\mathrm{Ca}$. Hal ini terbukti dari hasil uji nyata DMRT yang menunjukkan bahwa perlakuan Ko+N+P+K+Ca berpengaruh nyata terhadap pertumbuhan dan produksi jagung manis. Dengan demikian pemberian kaptan diperlukan untuk tindakan pemupukan selanjutnya. Kaptan selain dapat menetralisasi kemasaman tanah juga sekaligus menambahkan hara Ca. Berdasarkan nilai $R G B$ yang dihasilkan dari software ImageJ, terlihat bahwa semua perlakuan pemupukan teknik plus one test rata-rata menyebabkan penurunan nilai $R G B$ dibandingkan dengan perlakuan kontrol, kecuali perlakuan Ko+N mengalami peningkatan nilai $G$. Dengan demikian penambahan hara $\mathrm{N}, \mathrm{P}, \mathrm{K}, \mathrm{Ca}, \mathrm{Mg}$, dan $\mathrm{S}$ relatif mempengaruhi nilai $R G B$. Namun, nilai $G$ memiliki nilai tertinggi untuk setiap perlakuan pemupukan yang diberikan dibandingkan dengan nilai $R$ dan $B$. Walaupun demikian, semakin lengkap hara yang ditambahkan menyebabkan semakin meningkat serapan warna merah dan biru.

Kata kunci: Hara tersedia, warna daun, faktor pembatas

\section{PENDAHULUAN}

Metode evaluasi status hara dengan teknik percobaan plus one test dilakukan untuk mengetahui hara yang menjadi faktor pembatas. Metode ini berfungsi untuk memprediksi kekurangan hara yang dapat dilihat dari pertumbuhan dan produksi tanaman sehingga dapat mencerminkan kondisi hara di dalam media tanam (Safuan,
2007). Pada percobaan plus one test pengujian dilakukan dengan membandingkan perlakuan kontrol dengan perlakuan penambahan satu hara sampai perlakuan lengkap. Perlakuan yang mengalami kenaikan pertumbuhan atau produksi tanaman tertinggi menunjukkan unsur hara yang paling kekurangan (Nugroho, 1996; Leiwakabessy dan Sutandi, 2004). Hasil penelitian Setyorini et al. (2003) percobaan plus one test pada tanaman padi di Ultisol 
menunjukkan bahwa penambahan hara $\mathrm{N}, \mathrm{P}$, dan $\mathrm{K}$ dapat meningkatkan tinggi tanaman, sedangkan pada penambahan hara $\mathrm{Ca}, \mathrm{Mg}$, dan $\mathrm{S}$ tidak menunjukkan adanya peningkatan yang signifikan dalam pertumbuhan tanaman. Hal ini dikarenakan hara $\mathrm{Ca}, \mathrm{Mg}$, dan $\mathrm{S}$ di dalam tanah sudah dianggap cukup, maka jika dilakukan penambahan hara tersebut menyebabkan pertumbuhan tanaman menjadi terganggu.

Metode evaluasi status hara dengan teknik percobaan plus one test sangat bermanfaat meskipun mempunyai beberapa kelemahan diantaranya perlu waktu lama, biaya besar, dan tingkat kuantifikasi dari metode ini relatif masih kurang. Namun, metode ini dapat digunakan untuk mengembangkan metode evaluasi hara lainnya, baik melalui rancangan percobaan tertentu, berdasarkan batas kritis ketersediaan hara dalam tanah atau berdasarkan kecukupan hara dalam jaringan tanaman yang dapat pula diidentifikasi melalui warna daun. Selain itu, dari segi agronomik dapat dilihat dari pertumbuhan dan produksi tanaman, sehingga hasilnya meyakinkan dan dapat diinterpretasikan dengan tepat. Pertumbuhan tanaman dipengaruhi oleh ketersediaan hara dalam tanah sehingga apabila tanaman mengalami kekurangan salah satu hara, maka gejala kekurangan hara dapat terlihat dari warna daun. Daun tersebut mengalami gejala klorosis sehingga warna kehijauan pada daun akan berkurang. Waluyo et al. (2016) menyatakan bahwa warna daun merupakan indikator yang berguna bagi kebutuhan pupuk pada tanaman. Ukuran perubahan hara akibat perlakuan plus one test dapat dilihat dari nilai merah (red), hijau (green), dan biru (blue) $(R G B)$. Menurut Diaz et al. (2015) pemanfaatan nilai $R G B$ tersebut sudah dibuktikan cukup efektif dalam melihat gejala defisiensi hara daun pada tanaman mentimun.

Salah satu upaya yang dilakukan untuk mendapatkan informasi hara yang menjadi faktor pembatas pada lahan tertentu adalah dengan percobaan plus one test yang dilihat dari pertumbuhan dan produksi tanaman. Hasil evaluasi status hara tersebut digunakan untuk tindakan pemupukan selanjutnya. Penelitian ini bertujuan mengevaluasi pengaruh perlakuan pemupukan terhadap pertumbuhan, produksi dan warna daun jagung manis.

\section{BAHAN DAN METODE}

Penelitian dilaksanakan pada Latosol di Kebun Percobaan Cikabayan, Dramaga Bogor. Analisis tanah dilakukan di Laboratorium Kimia dan Kesuburan Tanah, Departemen Ilmu Tanah dan Sumberdaya Lahan, Fakultas Pertanian, IPB. Penelitian berlangsung dari September 2018 sampai Maret 2019.
Percobaan plus one test merupakan percobaan faktor tunggal dengan tujuh perlakuan yang ditempatkan dalam rancangan acak kelompok. Perlakuan diulang dua kali, sehingga diperoleh 14 satuan percobaan. Ukuran petak percobaan 2.4 x $5 \mathrm{~m}$. Pada masing-masing petak percobaan diberikan 10 ton ha- ${ }^{-1}$ kotoran domba sebagai pupuk dasar. Benih jagung manis ditanam dua benih per lubang tanam dengan jarak tanam 80 × $35 \mathrm{~cm}$. Penyulaman dilakukan ketika tanaman berumur $1 \mathrm{MST}$. Perlakuan plus one test tertera pada Tabel 1. Pupuk urea dan $\mathrm{KCl}$ diberikan tiga kali masing-masing sepertiga bagian pada saat tanam, 4 dan 8 Minggu Setelah Tanam (MST), sedangkan pupuk ZA diberikan dua kali pada saat tanam dan 4 MST.

Variabel percobaan yang diamati meliputi tinggi tanaman, bobot tongkol, dan bobot brangkasan jagung manis, serta warna daun jagung manis. Tinggi tanaman diukur pada umur 2, 4, 6 dan 8 MST. Setiap satuan percobaan diambil 5 tanaman contoh yang ditetapkan secara acak. Bobot tongkol dan bobot berangkasan ditetapkan pada saat panen jagung manis umur \pm 75 Hari Setelah Tanam (HST). Hara yang menjadi faktor pembatas pertumbuhan dan produksi tanaman ditentukan dengan menghitung peningkatan hasil (Leiwikabessy dan Sutandi, 2004) yaitu selisih antara perlakuan penambahan hara tertentu dengan perlakuan sebelumnya (tanpa penambahan hara tersebut). Semakin tinggi peningkatan hasil akibat penambahan suatu hara, maka semakin rendah ketersediaan hara tersebut dalam tanah. Sebaliknya, semakin rendah peningkatan hasil, maka semakin tinggi ketersediaan hara tersebut dalam tanah sehingga respon tanaman juga rendah.

Warna daun diambil pada daun penyangga tongkol saat rambut tongkol jagung masih putih (fase silking) di umur 9 MST dengan pengambilan tujuh contoh daun di setiap petaknya. Selanjutnya contoh daun tersebut dipindai dengan Canon scan model LIDE 210. Contoh tanah sebelum percobaan diambil pada petak percobaan untuk keperluan analisis sifat kimia tanah awal.

Sifat kimia tanah yang dianalisis yaitu $\mathrm{pH}$ tanah, $\mathrm{N}$-tersedia $\left(\mathrm{N}_{-} \mathrm{NO}_{3}{ }^{-}\right.$dan $\left.\mathrm{N}-\mathrm{NH}_{4}{ }^{+}\right), \mathrm{P}$-tersedia, S-tersedia, Kdd (kalium yang dapat dipertukarkan), Ca-dd (kalsium yang dapat dipertukarkan), dan $\mathrm{Mg}$-dd (magnesium yang dapat dipertukarkan). $\mathrm{pH}$ tanah $\mathrm{H}_{2} \mathrm{O}$ (1:5) diukur dengan metode glass electrode. Analisis $\mathrm{N}$-tersedia tanah ditentukan dengan metode ekstraksi campuran $\mathrm{KCl} 1 \mathrm{~N}$ dan $\mathrm{HCl} 0.1 \mathrm{~N}$ serta pengukurannya dengan destilasi dan titrasi, analisis $\mathrm{P}$ tersedia tanah ditetapkan dengan metode Bray-1, S-tersedia tanah dengan metode turbidimetri $\left(\mathrm{BaCl}_{2}\right.$-Tween), sedangkan analisis $\mathrm{K}$-dd, $\mathrm{Ca}-\mathrm{dd}$, dan $\mathrm{Mg}$-dd ditentukan dengan metode ekstraksi dengan $\mathrm{NH}_{4} \mathrm{O}_{\mathrm{Ac}}$ pH 7.0. Warna daun diidentifikasi dengan software ImageJ untuk menetapkan nilai Red, Green dan Blue (RGB) nya.

Tabel 1. Perlakuan dosis pupuk pada tanaman jagung manis

\begin{tabular}{|c|c|c|c|c|c|c|}
\hline \multirow[t]{2}{*}{ Perlakuan } & Urea & SP-36 & $\mathrm{KCl}$ & $\begin{array}{c}\text { Kapur } \\
\text { Pertanian } \\
\text { (Kaptan) }\end{array}$ & $\mathrm{MgO}$ & $\mathrm{ZA}$ \\
\hline & \multicolumn{6}{|c|}{$\mathrm{kg} \mathrm{ha}^{-1}$} \\
\hline Kontrol (Ko) & - & - & - & - & - & - \\
\hline $\mathrm{Ko}+\mathrm{N}$ & 300 & - & - & - & - & - \\
\hline $\mathrm{Ko}+\mathrm{N}+\mathrm{P}$ & 300 & 375 & - & - & - & - \\
\hline $\mathrm{Ko}+\mathrm{N}+\mathrm{P}+\mathrm{K}$ & 300 & 375 & 150 & - & - & - \\
\hline $\mathrm{Ko}+\mathrm{N}+\mathrm{P}+\mathrm{K}+\mathrm{Ca}$ & 300 & 375 & 150 & 1000 & - & - \\
\hline $\mathrm{Ko}+\mathrm{N}+\mathrm{P}+\mathrm{K}+\mathrm{Ca}+\mathrm{Mg}$ & 300 & 375 & 150 & 1000 & 40 & - \\
\hline $\mathrm{Ko}+\mathrm{N}+\mathrm{P}+\mathrm{K}+\mathrm{Ca}+\mathrm{Mg}+\mathrm{S}$ & 282.5 & 375 & 150 & 1000 & 40 & 83.3 \\
\hline
\end{tabular}


Data hasil pengamatan dianalisis statistik menggunakan analisis sidik ragam pada taraf $\alpha 5 \%$. Apabila hasilnya menunjukkan pengaruh beda nyata, dilanjutkan dengan uji lanjut Duncan's Multiple Range Test (DMRT) pada taraf $\alpha 5 \%$ untuk melihat pengaruh antar perlakuan dengan program SAS versi 9.0 .

\section{HASIL DAN PEMBAHASAN}

\section{Sifat Kimia Tanah Awal Sebelum Percobaan}

Berdasarkan penilaian sifat kimia tanah yang dikeluarkan Balai Penelitian Tanah tahun 2009 (Eviati dan Sulaeman, 2009), jenis tanah Latosol yang digunakan dalam penelitian ini rata-rata mempunyai $\mathrm{pH} \mathrm{H}_{2} \mathrm{O}$ agak masam ( $\mathrm{pH} 4.74$ sampai $\mathrm{pH} 4.86$ ) dan kandungan P-tersedia (PBray 1) termasuk kategori sedang (9.02 ppm). Kandungan $\mathrm{N}$-tersedia rata-rata sebesar $26.19 \mathrm{ppm}$, S-tersedia sebesar $46.81 \mathrm{ppm}$, dan Al-dd sebesar $0.81 \mathrm{cmol}(+) \mathrm{kg}^{-1}$. Kandungan K-dd (0.12 cmol(+) kg-1), Ca-dd (3.16 cmol(+) $\left.\mathrm{kg}^{-1}\right)$ dan $\mathrm{Mg}$-dd (0.74 cmol(+) $\mathrm{kg}^{-1}$ ) termasuk dalam kategori rendah. Berdasarkan sifat kimia tanah tersebut terlihat bahwa permasalahan pada Latosol Dramaga, Bogor adalah $\mathrm{pH}$ tanah yang masam dan kandungan basa-basa yang rendah.

\section{Hasil Percobaan Plus One Test dan Pengaruhnya terhadap Pertumbuhan dan Produksi Jagung Manis}

Berdasarkan metode evaluasi status hara plus one test pada tinggi tanaman diperoleh hasil bahwa hara $\mathrm{Ca}$ merupakan hara yang paling kurang, disusul dengan hara $\mathrm{N}$, $\mathrm{S}, \mathrm{P}$, dan Mg. Namun, hara $\mathrm{K}$ mempunyai kadar cukup, seperti terlihat dari penurunan tinggi tanaman akibat perlakuan penambahan hara $\mathrm{K}$ (perlakuan $\mathrm{Ko}+\mathrm{N}+\mathrm{P}+\mathrm{K}$ dikurangi perlakuan $\mathrm{Ko}+\mathrm{N}+\mathrm{P})$. Hasil sidik ragam menunjukkan bahwa perlakuan pemupukan plus one test berpengaruh nyata terhadap tinggi tanaman. Pada Tabel 2 terlihat bahwa perlakuan kontrol memiliki hasil yang nyata lebih rendah dibandingkan dengan perlakuan yang lain. Antar perlakuan $\mathrm{Ko}+\mathrm{N}+\mathrm{P}+\mathrm{K}+\mathrm{Ca}, \mathrm{Ko}+\mathrm{N}+\mathrm{P}+\mathrm{K}+\mathrm{Ca}+\mathrm{Mg}$ dan $\mathrm{Ko}+\mathrm{N}+\mathrm{P}+\mathrm{K}+\mathrm{Ca}+\mathrm{Mg}+\mathrm{S}$ memiliki tinggi tanaman yang tidak berbeda nyata. Namun, perlakuan tersebut nyata lebih tinggi dibandingkan dengan perlakuan yang lain. Perlakuan $\mathrm{Ko}+\mathrm{N}+\mathrm{P}+\mathrm{K}+\mathrm{Ca}$ mempunyai tinggi tanaman nyata lebih tinggi dibandingkan dengan perlakuan $\mathrm{Ko}+\mathrm{N}+\mathrm{P}+\mathrm{K}$ yang menunjukkan bahwa penambahan hara $\mathrm{Ca}$ dari kaptan memiliki pengaruh yang nyata dalam meningkatkan tinggi tanaman.

Selain hara $\mathrm{Ca}$, hara yang dapat meningkatkan tinggi tanaman secara signifikan adalah hara $\mathrm{N}$, sehingga dapat dikatakan bahwa hara $\mathrm{N}$ memiliki peran yang besar dalam pertumbuhan vegetatif jagung. Tanaman jagung menyerap separuh hara $\mathrm{N}$ dari total serapan pada periode pertumbuhan vegetatif. Kecukupan hara $\mathrm{N}$ pada fase vegetatif sangat penting untuk menjamin pertumbuhan dan produktivitas tanaman secara optimal (Syafruddin, 2015).

Hasil yang didapatkan dari metode plus one test untuk variabel bobot tongkol dan berangkasan jagung (Tabel 3 dan 4) menunjukkan bahwa hara $\mathrm{Ca}$ merupakan hara yang paling kurang disusul dengan hara $\mathrm{P}, \mathrm{N}$, dan $\mathrm{Mg}$, sedangkan untuk hara $\mathrm{S}$ dan $\mathrm{K}$ masuk ke dalam kategori cukup. Hasil uji lanjut DMRT menunjukkan bahwa pemberian kaptan (perlakuan $\mathrm{Ko}+\mathrm{N}+\mathrm{P}+\mathrm{K}+\mathrm{Ca}$ ) memiliki pengaruh yang nyata terhadap bobot tongkol dan berangkasan jagung. Hal ini terlihat bobot tongkol maupun bobot berangkasan jagung pada perlakuan $\mathrm{Ko}+\mathrm{N}+\mathrm{P}+\mathrm{K}+\mathrm{Ca}$ nyata lebih tinggi dibandingkan dengan perlakuan Kontrol, $\mathrm{Ko}+\mathrm{N}$, $\mathrm{Ko}+\mathrm{N}+\mathrm{P}$, dan $\mathrm{Ko}+\mathrm{N}+\mathrm{P}+\mathrm{K}$.

Tabel 2. Pengaruh perlakuan plus one test terhadap tinggi tanaman

\begin{tabular}{lcccc}
\hline \multirow{2}{*}{ Perlakuan } & \multirow{2}{*}{ Tinggi Tanaman* $(\mathrm{cm})$} & \multicolumn{2}{c}{ Peningkatan Tinggi Tanaman } & \multirow{2}{*}{ Kenaikan Tinggi Tanaman (\%) } \\
\cline { 3 - 4 } & $125.2 \mathrm{~d}$ & - & $\mathrm{cm}$ & \\
Kontrol $(\mathrm{Ko})$ & $148.8 \mathrm{~cd}$ & $\mathrm{~N}$ & 23.6 & 18.8 \\
Ko+N & $166.8 \mathrm{c}$ & $\mathrm{P}$ & 18 & 12.1 \\
Ko+N+P & $162.2 \mathrm{c}$ & $\mathrm{K}$ & -4.6 & -2.8 \\
Ko+N+P+K & $204.3 \mathrm{ab}$ & $\mathrm{Ca}$ & 42.1 & 26.0 \\
Ko+N+P+K+Ca & $214.0 \mathrm{a}$ & $\mathrm{Mg}$ & 9.7 & 4.7 \\
Ko+N+P+K+Ca+Mg & $236.5 \mathrm{a}$ & $\mathrm{S}$ & 22.5 & 10.5 \\
Ko+N+P+K+Ca+Mg+S & & &
\end{tabular}

Keterangan: *angka rata-rata yang diikuti dengan huruf yang sama pada satu kolom tidak berpengaruh nyata pada uji lanjut Duncan dengan taraf $\alpha$ 5\% * tinggi tanaman umur 8 MST

Tabel 3. Pengaruh perlakuan plus one test terhadap bobot tongkol jagung

\begin{tabular}{|c|c|c|c|c|}
\hline \multirow{2}{*}{ Perlakuan } & \multirow{2}{*}{ Bobot Tongkol* ${ }^{*} \mathrm{~kg}$ petak $\left.^{-1}\right)$} & \multicolumn{2}{|c|}{ Peningkatan Bobot Tongkol } & \multirow{2}{*}{ Kenaikan Bobot Tongkol (\%) } \\
\hline & & Hara & $\mathrm{kg} \mathrm{petak}^{-1}$ & \\
\hline Kontrol (Ko) & $4.7 \mathrm{~d}$ & - & - & \\
\hline $\mathrm{Ko}+\mathrm{N}$ & $6.5 \mathrm{~cd}$ & $\mathrm{~N}$ & 1.8 & 38.3 \\
\hline $\mathrm{Ko}+\mathrm{N}+\mathrm{P}$ & $10.3 \mathrm{~b}$ & $\mathrm{P}$ & 3.8 & 58.5 \\
\hline $\mathrm{Ko}+\mathrm{N}+\mathrm{P}+\mathrm{K}$ & $8.5 \mathrm{bc}$ & $\mathrm{K}$ & -1.8 & -17.5 \\
\hline $\mathrm{Ko}+\mathrm{N}+\mathrm{P}+\mathrm{K}+\mathrm{Ca}$ & $16.1 \mathrm{a}$ & $\mathrm{Ca}$ & 7.6 & 89.4 \\
\hline $\mathrm{Ko}+\mathrm{N}+\mathrm{P}+\mathrm{K}+\mathrm{Ca}+\mathrm{Mg}$ & $16.2 \mathrm{a}$ & $\mathrm{Mg}$ & 0.1 & 0.6 \\
\hline $\mathrm{Ko}+\mathrm{N}+\mathrm{P}+\mathrm{K}+\mathrm{Ca}+\mathrm{Mg}+\mathrm{S}$ & $15.1 \mathrm{a}$ & $\mathrm{S}$ & -1.1 & -6.8 \\
\hline
\end{tabular}

Keterangan: *angka rata-rata yang diikuti dengan huruf yang sama pada satu kolom tidak berpengaruh nyata pada uji lanjut Duncan dengan taraf $\alpha$ 5\% 
Tabel 4. Pengaruh perlakuan plus one test terhadap bobot berangkasan jagung

\begin{tabular}{|c|c|c|c|c|}
\hline \multirow{2}{*}{ Perlakuan } & \multirow{2}{*}{ Bobot Berangkasan* $\left(\mathrm{kg}\right.$ petak $\left.^{-1}\right)$} & \multicolumn{2}{|c|}{ Peningkatan Bobot Berangkasan } & \multirow{2}{*}{ Kenaikan Bobot Berangkasan (\%) } \\
\hline & & Hara & $\mathrm{kg} \mathrm{petak}^{-1}$ & \\
\hline Kontrol (Ko) & $10.6 \mathrm{c}$ & - & - & \\
\hline $\mathrm{Ko}+\mathrm{N}$ & $13.4 \mathrm{c}$ & $\mathrm{N}$ & 2.8 & 26.4 \\
\hline $\mathrm{Ko}+\mathrm{N}+\mathrm{P}$ & $21.5 \mathrm{~b}$ & $\mathrm{P}$ & 8.1 & 60.4 \\
\hline $\mathrm{Ko}+\mathrm{N}+\mathrm{P}+\mathrm{K}$ & $18.4 \mathrm{~b}$ & $\mathrm{~K}$ & -3.1 & -14.4 \\
\hline $\mathrm{Ko}+\mathrm{N}+\mathrm{P}+\mathrm{K}+\mathrm{Ca}$ & $35.7 \mathrm{a}$ & $\mathrm{Ca}$ & 17.3 & 94.0 \\
\hline $\mathrm{Ko}+\mathrm{N}+\mathrm{P}+\mathrm{K}+\mathrm{Ca}+\mathrm{Mg}$ & $35.8 \mathrm{a}$ & $\mathrm{Mg}$ & 0.1 & 0.3 \\
\hline $\mathrm{Ko}+\mathrm{N}+\mathrm{P}+\mathrm{K}+\mathrm{Ca}+\mathrm{Mg}+\mathrm{S}$ & $33.4 \mathrm{a}$ & $\mathrm{S}$ & -2.4 & -6.7 \\
\hline
\end{tabular}

Keterangan: *angka rata-rata yang diikuti dengan huruf yang sama pada satu kolom tidak berpengaruh nyata pada uji lanjut Duncan dengan taraf $\alpha$ \%

Sitko et al. (2019) menyatakan bahwa hara $\mathrm{Ca}$, $\mathrm{Mg}$, dan $\mathrm{K}$ dibutuhkan tanaman pada fase fotosintesis yang selanjutnya berpengaruh terhadap bobot tongkol maupun berangkasan jagung. Hasil penelitian ini menunjukkan bahwa bobot tongkol maupun berangkasan jagung meningkat diduga dengan adanya penambahan hara $\mathrm{Ca}$ dan $\mathrm{Mg}$ melalui kaptan dan $\mathrm{MgO}$. Hal ini berarti tanaman tersebut dapat menyerap sinar matahari dan hara dengan baik sehingga proses fotosintesis berjalan dengan baik. Kaptan selain dapat menetralisasi kemasaman tanah juga sekaligus menambahkan hara $\mathrm{Ca}$. Peningkatan $\mathrm{pH}$ tanah dapat meningkatkan ketersediaan hara lainnya dan serapan hara tanaman jagung. Kalsium (Ca) merupakan hara sangat penting dalam tanaman, secara positif mempengaruhi pertumbuhan secara keseluruhan (Sacała et al., 2005).

Berdasarkan Tabel 3 dan 4 juga terlihat bahwa penambahan hara $\mathrm{P}$ dapat meningkatkan bobot tongkol dan berangkasan jagung. Oleh sebab itu, dapat dikatakan bahwa hara $\mathrm{P}$ memiliki peran yang tinggi pada fase generatif jagung. Hal tersebut selaras dengan penelitian Pasta et al. (2015) yang menyatakan bahwa hara $\mathrm{P}$ memiliki peran dalam proses pembentukkan biji atau buah tanaman pada fase generatif.

\section{Pengaruh Teknik Percobaan Plus One Test terhadap Warna Daun}

Kondisi visual tanaman dapat menggambarkan pertumbuhan dan perkembangan tanaman. Kondisi visual tanaman tersebut dapat dilihat melalui warna daun yang dapat diambil dengan berbagai cara. Menurut Diaz et al. (2015) analisis citra (image analysis) dapat dilakukan pada citra fotografi maupun citra pindai yang memanfaatkan nilai $R G B$ nya. Pemanfaatan nilai $R G B$ (red, green, blue) dapat digunakan untuk mengidentifikasi perubahan warna dalam pencegahan tanaman kekurangan hara dengan pemanfaatan foto digital untuk mendeteksi kekurangan hara yang tidak membutuhkan waktu yang lama dan biaya murah (Hashim et al., 2010). Citra digital yang dihasilkan dalam penelitian ini merupakan hasil proses pemindaian daun jagung pada saat silking dalam format .jpg.

Secara teori klorofil menyerap cahaya berpusat pada panjang gelombang merah dan biru pada saat pertumbuhan, sedangkan untuk gelombang hijau hanya akan diserap sedikit dan dipantulkan kembali. Lillesand dan Kiefer (1997) menyatakan bahwa reflektan warna daun yang dihasilkan didominasi oleh warna hijau, sedangkan warna merah dan biru akan diserap tanaman. Hal tersebut yang membuat warna hijau menjadi tampak pada daun yang sehat. Jika warna daun tidak sepenuhnya berwarna hijau, maka terjadinya gangguan dalam penyerapan warna merah dan biru yang diduga karena tanaman tersebut mengalami kekurangan hara.

Berdasarkan nilai $R G B$ yang dihasilkan dari software ImageJ (Gambar 1), terlihat bahwa semua perlakuan pemupukan teknik plus one test (penambahan hara $\mathrm{N}, \mathrm{P}, \mathrm{K}, \mathrm{Ca}, \mathrm{Mg}$, dan $\mathrm{S}$ ) rata-rata menyebabkan penurunan nilai $R G B$ dibandingkan dengan perlakuan kontrol, kecuali perlakuan $\mathrm{Ko}+\mathrm{N}$ mengalami peningkatan nilai $G$. Dengan demikian penambahan hara $\mathrm{N}, \mathrm{P}, \mathrm{K}, \mathrm{Ca}$, $\mathrm{Mg}$, dan $\mathrm{S}$ relatif mempengaruhi nilai $R G B$ (Gambar 2). Namun, nilai $G$ memiliki nilai tertinggi untuk setiap perlakuan pemupukan yang diberikan dibandingkan dengan $R$ dan $B$. Walaupun demikian, semakin lengkap hara yang ditambahkan menyebabkan semakin meningkat serapan warna merah dan biru.

Cara identifikasi ini merupakan langkah awal dalam teknik identifikasi hara. Berbagai hal perlu diperhatikan dalam identifikasi berdasarkan warna tersebut diantaranya adalah ketelitian pemindai yang digunakan, sinar yang digunakan pemindai, kerataan permukaan contoh daun dengan tulang daun dihilangkan, peletakan daun yang seragam terhadap permukaan pemindai (scanner), kebersihan contoh daun, waktu pengambilan contoh daun dengan pemindaian harus dalam satu waktu, kesamaan jarak terhadap permukaan pemindai, variabel warna, teknik analisis warna (total atau dengan pemisahan warna) dan lain-lain. Dalam penelitian ini digunakan pemindai dengan ketelitian sebesar 600 dpi, sinar warna putih dan daun jagung tanpa penghilangan tulang tengah daunnya. Menurut Allen dan Triantaphillidou (2011) nilai RGB pada suatu citra ditentukan oleh karakteristik pemindai sehingga jika resolusi citra rendah dapat memberikan nilai warna pada citra yang rendah. Selain itu penggunaan tipe scanner dapat memengaruhi kualitas gambar, tipe pemindai yang digunakan berupa pemindai flatbed yang sensor CCD nya hanya memiliki 3 filter berupa red, green, dan blue, sedangkan reflektan yang menggambarkan tanaman sehat (memiliki klorofil) dapat dihasilkan dari nilai reflektan inframerah yang tinggi yang tidak difasilitasi pada tipe pemindai flatbed yang dipakai pada penelitian ini. 


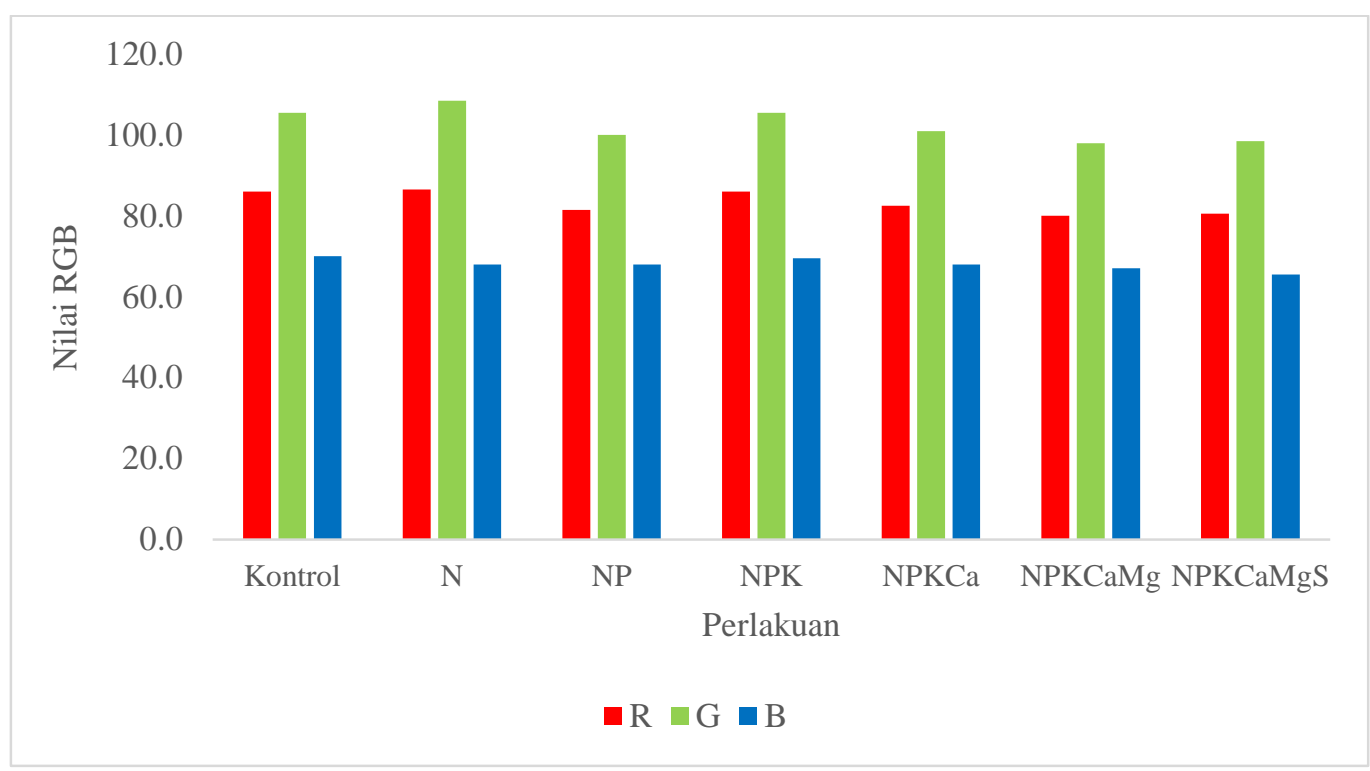

Gambar 1. Nilai RGB untuk setiap perlakuan

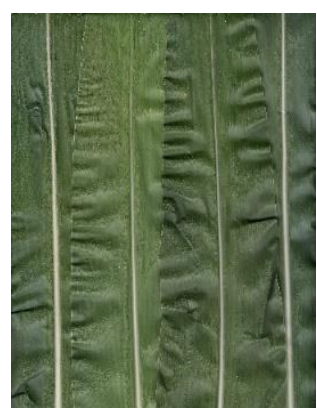

(a)

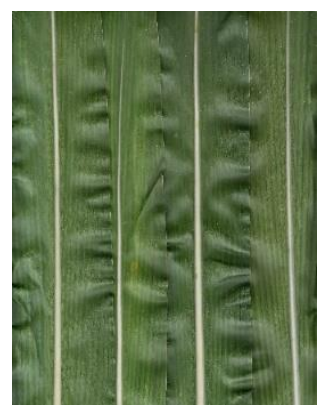

(b)

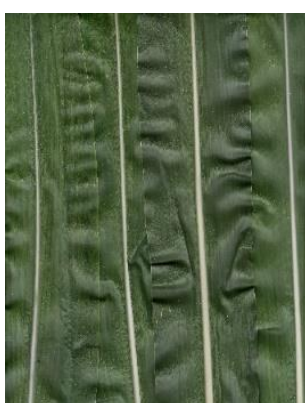

(c)

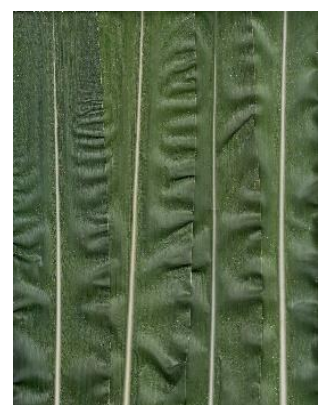

(d)

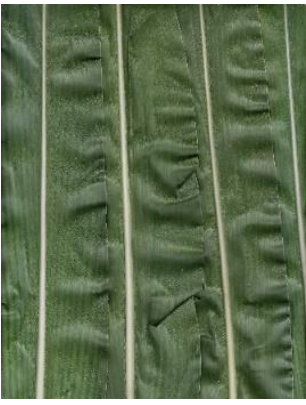

(e)

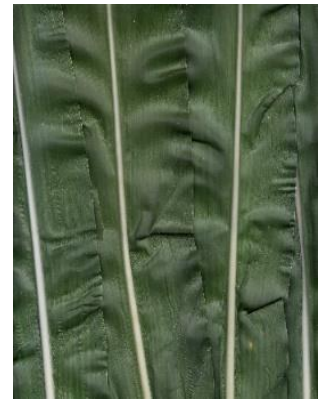

(f)

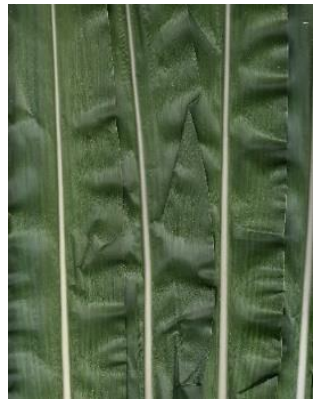

(g)

Gambar 2. Hasil scanning daun pada perlakuan $\mathrm{Ko}(\mathrm{a}), \mathrm{Ko}+\mathrm{N}(\mathrm{b}), \mathrm{Ko}+\mathrm{N}+\mathrm{P}(\mathrm{c}), \mathrm{Ko}+\mathrm{N}+\mathrm{P}+\mathrm{K}(\mathrm{d}), \mathrm{Ko}+\mathrm{N}+\mathrm{P}+\mathrm{K}+\mathrm{Ca}(\mathrm{e}), \mathrm{Ko}+\mathrm{N}+\mathrm{P}+\mathrm{K}+\mathrm{Ca}+\mathrm{Mg}$ (f), $\mathrm{Ko}+\mathrm{N}+\mathrm{P}+\mathrm{K}+\mathrm{Ca}+\mathrm{Mg}+\mathrm{S}(\mathrm{g})$

\section{SIMPULAN}

Percobaan metode evaluasi status hara tanah plus one test dengan pemberian kotoran domba 10 ton ha- ${ }^{-1}$ sebagai pupuk dasar menunjukkan bahwa hara yang menjadi faktor pembatas adalah $\mathrm{Ca}$. Hal ini terbukti dari hasil uji nyata DMRT yang menunjukkan bahwa perlakuan $\mathrm{Ko}+\mathrm{N}+\mathrm{P}+\mathrm{K}+\mathrm{Ca}$ berpengaruh nyata lebih tinggi dibandingkan dengan perlakuan Kontrol, $\mathrm{Ko}+\mathrm{N}, \mathrm{Ko}+\mathrm{N}+\mathrm{P}$, dan $\mathrm{Ko}+\mathrm{N}+\mathrm{P}+\mathrm{K}$ terhadap pertumbuhan dan produksi jagung manis. Dengan demikian pemberian kaptan diperlukan untuk tindakan pemupukan selanjutnya. Kaptan selain dapat menetralisasi kemasaman tanah juga sekaligus menambahkan hara $\mathrm{Ca}$. Berdasarkan nilai $R G B$ terlihat bahwa semua perlakuan pemupukan teknik plus one test (penambahan hara $\mathrm{N}, \mathrm{P}, \mathrm{K}, \mathrm{Ca}, \mathrm{Mg}$, dan $\mathrm{S}$ ) rata-rata menyebabkan penurunan nilai $R G B$ dibandingkan dengan perlakuan kontrol, kecuali perlakuan $\mathrm{Ko}+\mathrm{N}$ mengalami peningkatan nilai $G$. Dengan demikian penambahan hara N, $\mathrm{P}, \mathrm{K}, \mathrm{Ca}, \mathrm{Mg}$, dan $\mathrm{S}$ relatif mempengaruhi nilai $R G B$. Namun, nilai $G$ memiliki nilai tertinggi untuk setiap perlakuan pemupukan yang diberikan dibandingkan dengan nilai $R$ dan $B$. Walaupun demikian, semakin lengkap hara yang ditambahkan menyebabkan semakin meningkat serapan warna merah dan biru.

\section{DAFTAR PUSTAKA}

Aisyah, A., I.W. Suastika dan R. Suntari, 2015. Pengaruh aplikasi beberapa pupuk sulfur terhadap residu, serapan, serta produksi tanaman jagung di Mollisol 
Jonggol, Bogor, Jawa Barat. Jurnal Tanah dan Sumberdaya Lahan, 2(1): 93-101.

Allen, E. and S. Triantaphillidou. 2011. The Manual of Photography. Tenth edition. Focal Press Book.

Diaz, O.V., S.C. Kefauver, A. Elazab, M.T.N. Taladriz and J.L. Araus. 2015. Grainyield losses in yellow-rusted drum wheat estimated using digital Anaconventional parameter under field conditions. The Crop Journal, 3: 2000-2010.

Eviati dan Sulaeman. 2009. Petunjuk Teknis Jilid 2: Analisis Kimia Tanah, Tanaman, Air, dan Pupuk. Balai Penelitian Tanah, Bogor.

Fi'iliyah, Nurjaya dan Yekhfani. 2016. Pengaruh pemberian pupuk $\mathrm{KCl}$ terhadap $\mathrm{N}, \mathrm{P}, \mathrm{K}$ tanah dan serapan tanaman pada Inceptisol untuk tanaman jagung di Situ Hilir, Cibungbulang, Bogor. Jurnal Tanah dan Sumberdaya Lahan, 3(2): 329-337.

Hashim, N., R.L. Janius, Baranyai, M. Pflanz, C. Regen and M. Zude. 2010. Application of RGB and backscattering imaging to detect chiling injury symptoms in banana. CIGR workshop on image Analysis in Agriculture, Budapest.

Leiwakabessy, F.M. dan A. Sutandi. 2004. Pupuk dan Pemupukan. Departemen Tanah, Fakultas Pertanian, IPB, Bogor.

Lillesand, T.M. and R.W. Kiefer. 1997. Penginderaan Jauh dan Interpretasi Citra. Dulbahri, Suharsono P, Hartono, Suharyadi, penerjemah. Gadjah Mada University Press, Yogyakarta.

Luna, A.M., E.R. Garcia, A.L. Herrera, G.S. Zarazua, R.O. Velazquez, R.G. Gonzalez, G.H. Rulz and I.T. Pacheco. 2010. Nitrogen determination on tomato (Lycopersicon esculentum Mill) seedlings by color image analysis (RGB). Journal of Biotechnology, 9(33): 5326-5332.

Nugroho, B. 1996. Petak pemupukan dan percobaan Minus One Test. Disajikan dalam Pelatihan Pembinaan Uji Tanah dan Analisis Tanaman, Kerjasama antara Fakultas Pertanina, IPB dengan Agriculture Research and Management Project (ARMP). Bogor, 25 November - 7 Desember 1996.
Pasta, I., A. Ette dan H.N. Barus. 2015. Tanggap pertumbuhan dan hasil tanaman jagung manis (Zea mays L. Saccharata) pada aplikasi berbagai pupuk organik. Jurnal Agrotekbis, 3(2): 168-177.

Rosmarkam, A. dan N.W. Yuwono. 2002. Ilmu Kesuburan Tanah. Kanisius, Yogyakarta.

Sacała, E., A. Biegun, A. Demczuk and E. Grzys. 2005. Effect of $\mathrm{NaCl}$ and supplemental calcium on growth parameters and nitrate reductase activity in Maize. Acta Soc. Bot. Pol., 74: 119-123.

Safuan, L.O. 2007. Penyususnan rekomendasi pemupukan $\mathrm{N}$, P, dan $\mathrm{K}$ pada tanaman nenas (Ananas comosus (L) Merr.) smooth cayenne berdasarkan status hara tanah [Disertasi]. IPB. Bogor.

Setyorini, D., J.S. Adiningsih dan S. Rochayati. 2003. Uji Tanah Sebagai Dasar Penyusunan Rekomendasi Pemupukan. Agro Inovasi, Bogor.

Sitko, K., Z. Gieron, M. Szopiński, P.Z. Rusinowska, S. Rusinowski, M. Pogrzeba, A.D. Golec, H.M. Kalaji and E. Małkowski. 2019. Influence of short-term macronutrient deprivation in maize on photosynthetic characteristics, transpiration and pigment content. Scientific Reports, 9: 141818. https://doi.org/10.1038/s41598-019-50579-1.

Suharto, T.R.O., T.C. Setiawati dan S. Winarso. 2018. Peningkatan ketersediaan dan serapan $\mathrm{P}$ pada tanaman jagung di lahan tercemar limbah padat kapur (lime mud) melalui penambahan bahan organik. Jurnal Agroteknologi Universitas Andalas, 2(2): 1-10.

Suntoro, J. Syamsiah dan W Rahina. 2017. Ketersediaan dan serapan Ca pada kacang tanah yang diberi abu vulkanik kelud dan pupuk kandang. Agrosains, 19(2): 51-57.

Syafruddin. 2015. Manajemen pemupukan nitrogen pada tanaman jagung. Jurnal Litbang Pertanian, 34(3): 105-116.

Waluyo, W.W.S., S. Suharti dan L. Abdullah. 2016. Metode cepat pendugaan kandungan protein kasar pada rumput raja (pennisetum purpurhoides) menggunakan nilai indeks warna daun. Pasutra, 5(2): 76-82. 